\title{
Sistem Pelayanan Surat Administrasi Masyarakat Gampong Berbasis Webbase dengan menggunakan Framework CodeIgniter
}

\author{
Munawir $^{1^{*}}$, Susmanto ${ }^{2}$, Zulfan $^{3}$, Yeni Yanti ${ }^{4}$ \\ ${ }^{1,2,3,4}$ Prodi Teknik Komputer, Fakultas Teknik, Universitas Serambi Mekkah \\ *Koresponden email : munawir@serambimekkah.ac.id
}

Diterima: 30 November 2019

Disetujui: 4 Desember 2019

\begin{abstract}
Service Standards are benchmarks that are used as guidelines for service delivery and references as a Service Standards are benchmarks used as quality assessment guidelines service to the community as a quality service, fast, easy, affordable, and measurable. At this time the development of technology and information systems increasingly stringent so that it requires the readiness of a technology that is able to answer competition in the government environment. Service data processing information systems in Gampong currently do not meet technological development standards in the present, because the existing data processing systems are still done manually using MS. Word and MS. EXCEL. The problem of service if you make a letter by hand is that the people who make the letter have to wait a long time, so the village officials must input the data manually. The purpose of this research is to produce a system in serving the public to make the documents needed by the community, so that the officers can provide services quickly and accurately. of the Village Administration, with the existence of this information system can provide services in the village administration data collection that previously was still using the manual system method.
\end{abstract}

Keywords: application, correspondence, village administration, service, webbase

\begin{abstract}
Abstrak
Standar Pelayanan adalah tolak ukur yang dipergunakan sebagai pedoman penyelenggaraan pelayanan dan acuan sebagai penilaian kualitas pelayanan, kewajiban dan janji penyelenggara pelayanan kepada masyarakat sebagai pelayanan yang berkualitas, cepat, mudah, terjangkau, dan terukur. Pada saat ini perkembangan teknologi dan sistem informasi semakin ketat sehingga memerlukan kesiapan suatu teknologi yang mampu menjawab persaingan di lingkungan pemerintah. Instansi Pemerintah yang bergerak melayani kebutuhan masyarakat. sistem informasi pengolahan data pelayanan di Gampong sekarang ini belum memenuhi standar perkembangan Teknologi dimasa kini, dikarenakan sistem pengolahan data yang ada masih dilakukan secara manual dengan menggunakan MS.Word dan MS. EXCEL. Permasalahan pelayanan jika membuat surat dengan cara manual masyarakat yang membuat surat harus menunggu lama, sehingga petugas gampong harus menginput data cara manual. Tujuan dari penelitian ini adalah untuk menghasilkan suatu sistem dalam melayani masyarakat membuat surat-surat yang dibutuhkan oleh masyarakat, sehingga petugas bisa memberikan pelayanan secara cepat dan tepat. Hasil dari penelitian ini adalah Sistem informasi yang dirancang dapat memberikan kemudahan serta dengan pembaruan pengurusan adminitrasi Gampong, dengan adanya sistem informasi ini dapat memberikan pelayanan dalam pendataan adminitrasi Gampong yang sebelumnya masih menggunakan metode manual sistem.
\end{abstract}

Kata Kunci: aplikasi, administrasi gampong, pelayanan, surat, webbase.

\section{Pendahuluan}

Pelayanan publik yang berkualitas atau yang biasa disebut dengan pelayanan prima merupakan pelayanan terbaik yang memenuhi standar kualitas pelayanan[1]. Standar Pelayanan adalah tolak ukur yang dipergunakan sebagai pedoman penyelenggaraan pelayanan dan acuan penilaian kualitas pelayanan sebagai kewajiban dan janji penyelenggara pelayanan kepada masyarakat dalam rangka pelayanan yang berkualitas, cepat, mudah, terjangkau, dan terukur [2]. Menurut Peraturan Menteri Pendayagunaan Aparatur Negara Dan Reformasi Birokrasi Republik Indonesia Nomor 15 Tahun 2014 [3], komponen standar pelayanan yang terkait dengan proses penyampaian pelayanan meliputi Persyaratan, prosedur, jangka waktu pelayanan, biaya/tarif, produk pelayanan, dan penanganan pengaduan. Jika suatu instansi 
pemerintah dan lembaga lainnya mampu menerapkan standar kualitas tersebut maka sudah dapat dikatakan bahwa Instansi pemerintah dan lembaga tersebut telah memberikan kualitas pelayanan yang baik [4].

Pada saat ini perkembangan teknologi dalam sistem informasi semakin ketat dan memerlukan kesiapan organisasi untuk teknologi yang mampu menjawab persaingan yang terjadi di lingkungan pemerintah. Salah satu unsur yang sangat mendasar di dalam dunia informasi adalah transformasi dan penyajian data secara cepat, akurat dan efisien [5]. Sistem adalah rangkaian dari dua atau lebih komponen-komponen yang saling berhubungan, yang berinteraksi untuk mencapai suatu tujuan. Sebagian besar sistem terdiri dari subsistem yang lebih kecil yang mendukung sistem yang lebih besar [6]. Sebuah sistem sebaik apapun jika penyaluran informasi dan penyajian datanya kurang efisien maka sistem itu akan melambat dan akhirnya benar -benar tidak berjalan.

Penggunaan sistem informasi pengolahan data pelayanan umum di gampong (kampung, sebutan di Aceh) yang ada sekarang ini belum memenuhi standar perkembangan teknologi dimasa kini dikarenakan sistem pengolahan data masih dilakukan secara manual dengan menggunakan MS. Word dan MS. EXCEL [7].

Dengan permasalahan yang dialami oleh setiap gampong dalam melayani masyarakat untuk membuat suatu surat administrasi atau surat - surat lainnya [8] maka perlu diadakan penelitian dan kajian terkait perancangan aplikasi untuk membantu menyelesaikan permasalahan tersebut. Tujuan penelitian adalah untuk merancang sistem informasi pada gampong yang mampu mengolah informasi yang cepat, akurat dan efisien sehingga lebih memberikan manfaat.

\section{Metode Penelitian}

\subsection{Proses Flowmap Berjalan}

Warga menyerahkan data kependudukan kepada pihak petugas kemudia petugas menginput seluruh data warga kedalam buku agenda [9]. Dalam proses permohonan warga terhadap kantor keuchik, warga menyerahkan data NIK kepada petugas untuk melakukan proses permohonan warga, setelah itu bagian petugas membuat surat-surat yang sesuai permintaan warga[10]. Petugas mencetak laporan surat dan menyerahkan kepada pimpinan untuk dievaluasi. Petugas mengarsip laporan surat yang telah di evaluasi oleh pimpinan serta menyerahkan kepada warga [11].

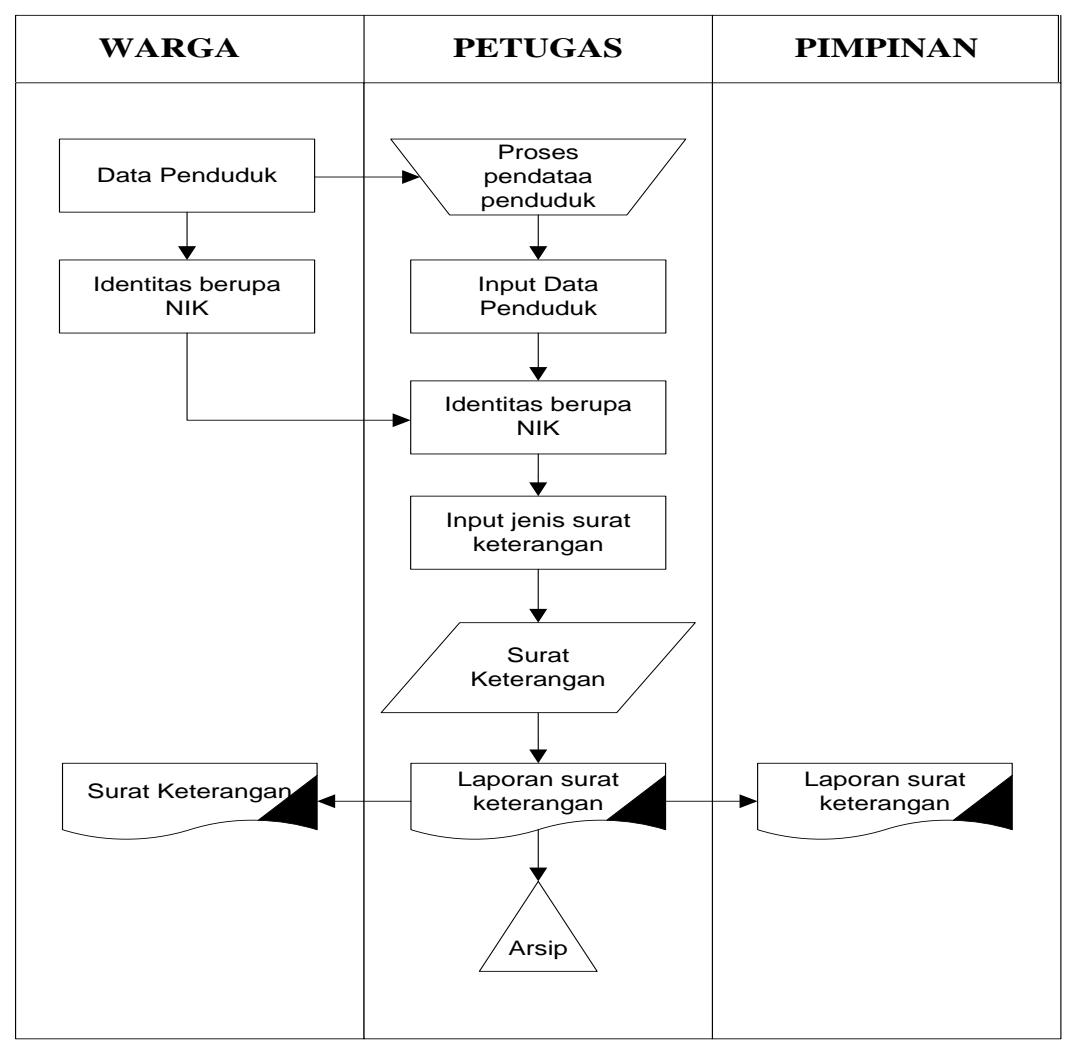

Gambar 1. Flowmap berjalan 


\subsection{Flowmap Usulan}

Warga menyerahkan data kependudukan kepada pihak petugas sehingga petugas dapat menginput seluruh data warga ke dalam sistem database [12]. Dalam proses permohonan warga terhadap kantor keuchik (kepala desa), warga menyerahkan data NIK kepada petugas untuk melakukan proses permohonan warga, setelah itu petugas membuat surat-surat yang sesuai permintaan warga dengan mudah yang sudah terdapat dalam sistem database. Petugas mencetak laporan surat dan menyerahkan kepada pimpinan untuk dievaluasi. Webbase [13]. Petugas mengarsip laporan surat yang telah dievaluasi oleh pimpinan serta menyerahkan kepada warga.

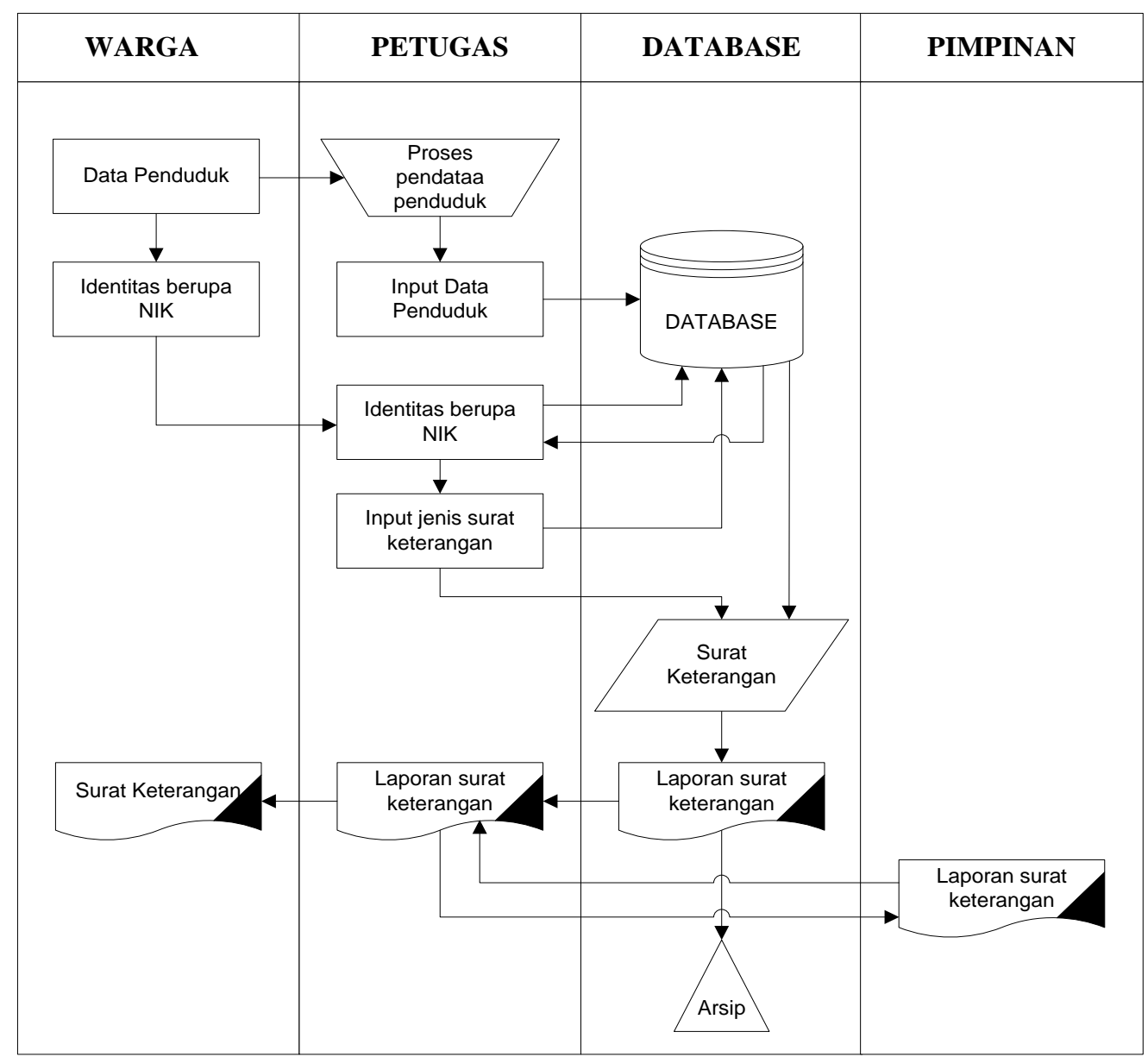

Gambar 2. Flowmap usulan

\subsection{Rancangan Entity Relationship Diagram (ERD)}

Entity Relationship Diagram merupakan suatu model untuk mejelaskan hubungan antar data dalam basis data berdasarkan objek-objek dasar data yang mempunyai hubungan antar relasi [14]. 


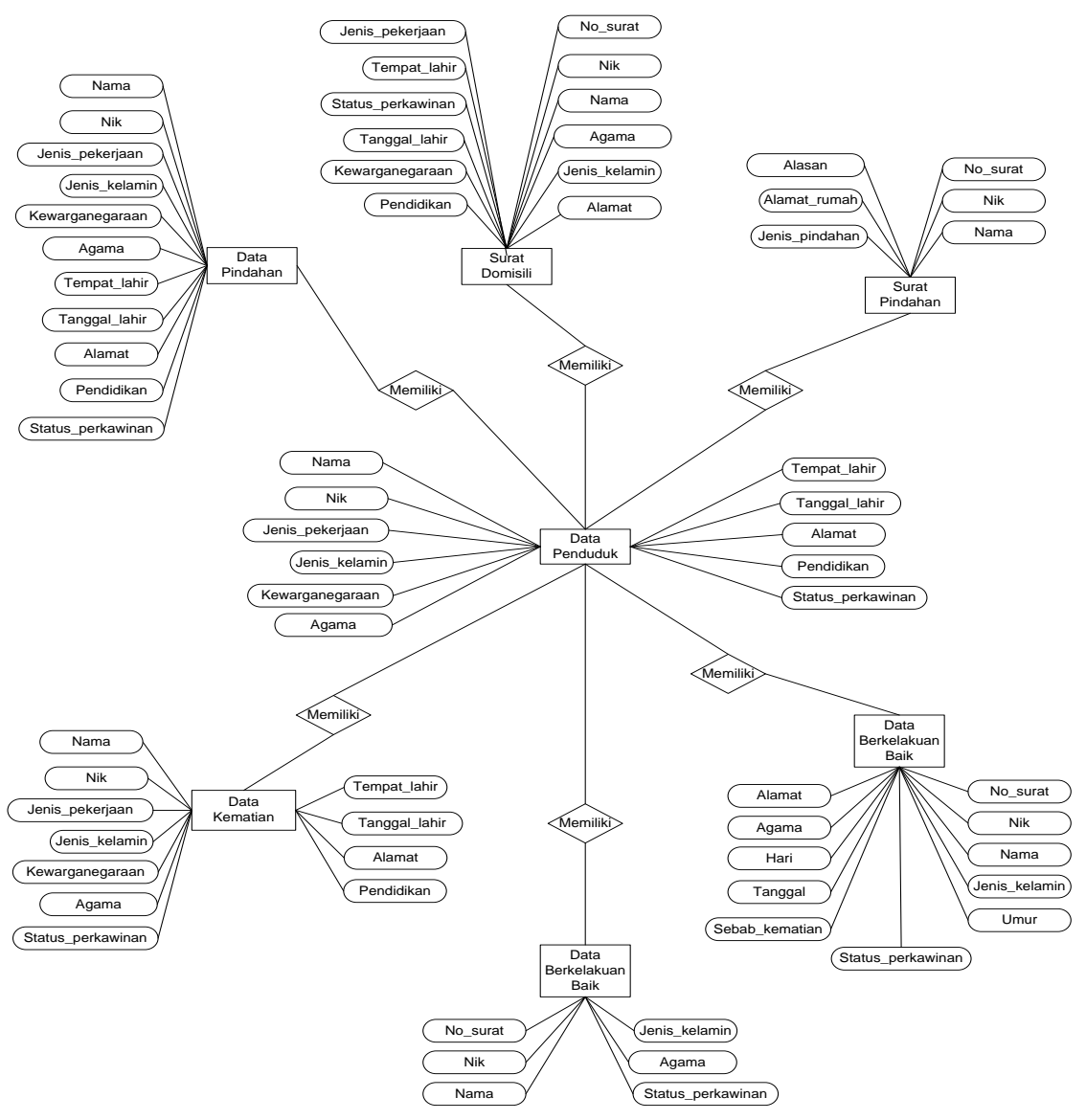

Gambar 3. ERD

\subsection{Diagram Konteks}

Diagram konteks digunakan untuk menggambarkan sistem pengolahan data secara keseluruhan. Diagram konteks ini dirancang memperhatikan masukan yang dibutuhkan oleh sistem dan keluaran yang dihasilkan oleh sistem [15].

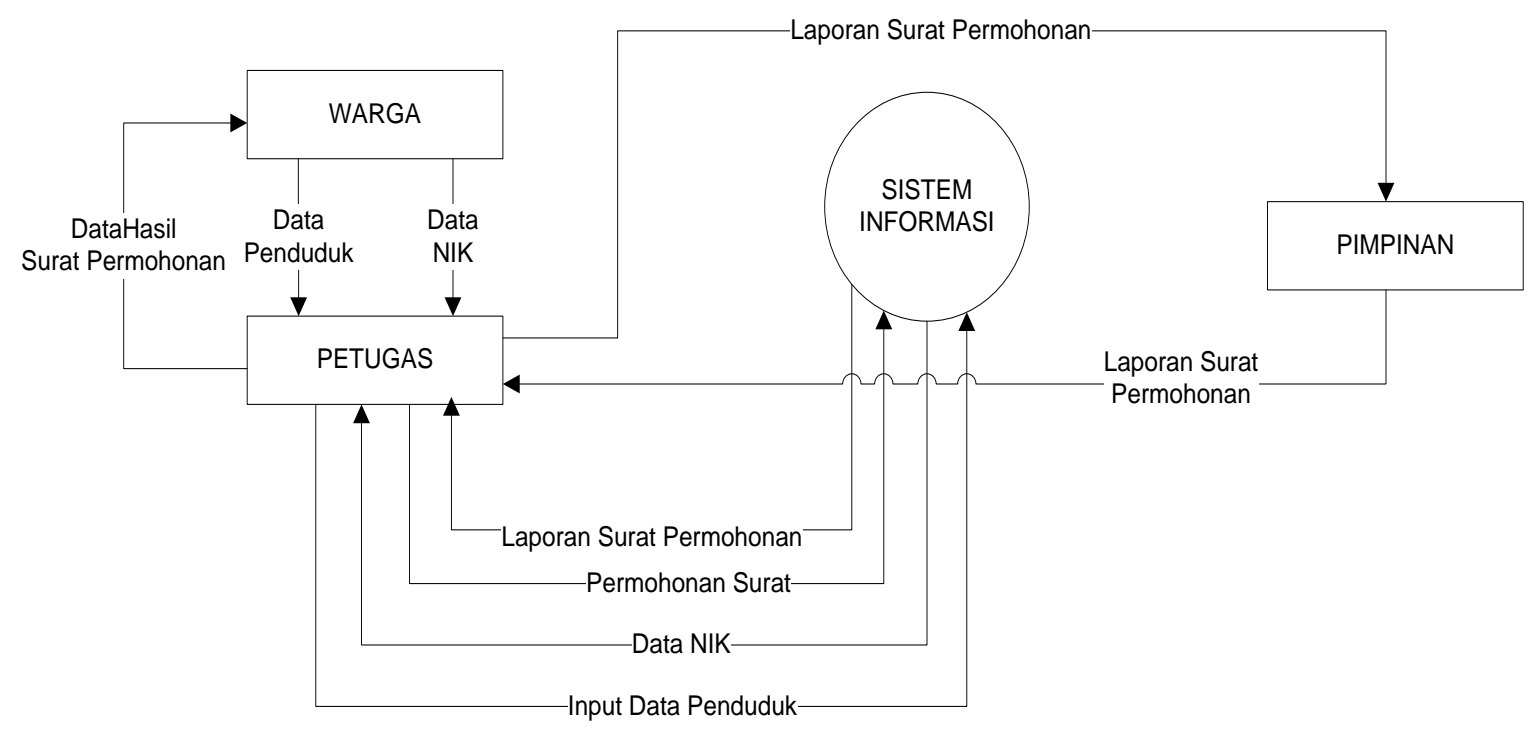

Gambar 4. Diagram konteks

\subsection{Relasi database}

Relasi tabel digunakan untuk mengelompokkan data menjadi tabel-tabel yang menunjukkan entitas dan relasi yang berfungsi untuk mengakses data sehingga database tersebut mudah dimodifikasi [16]. 


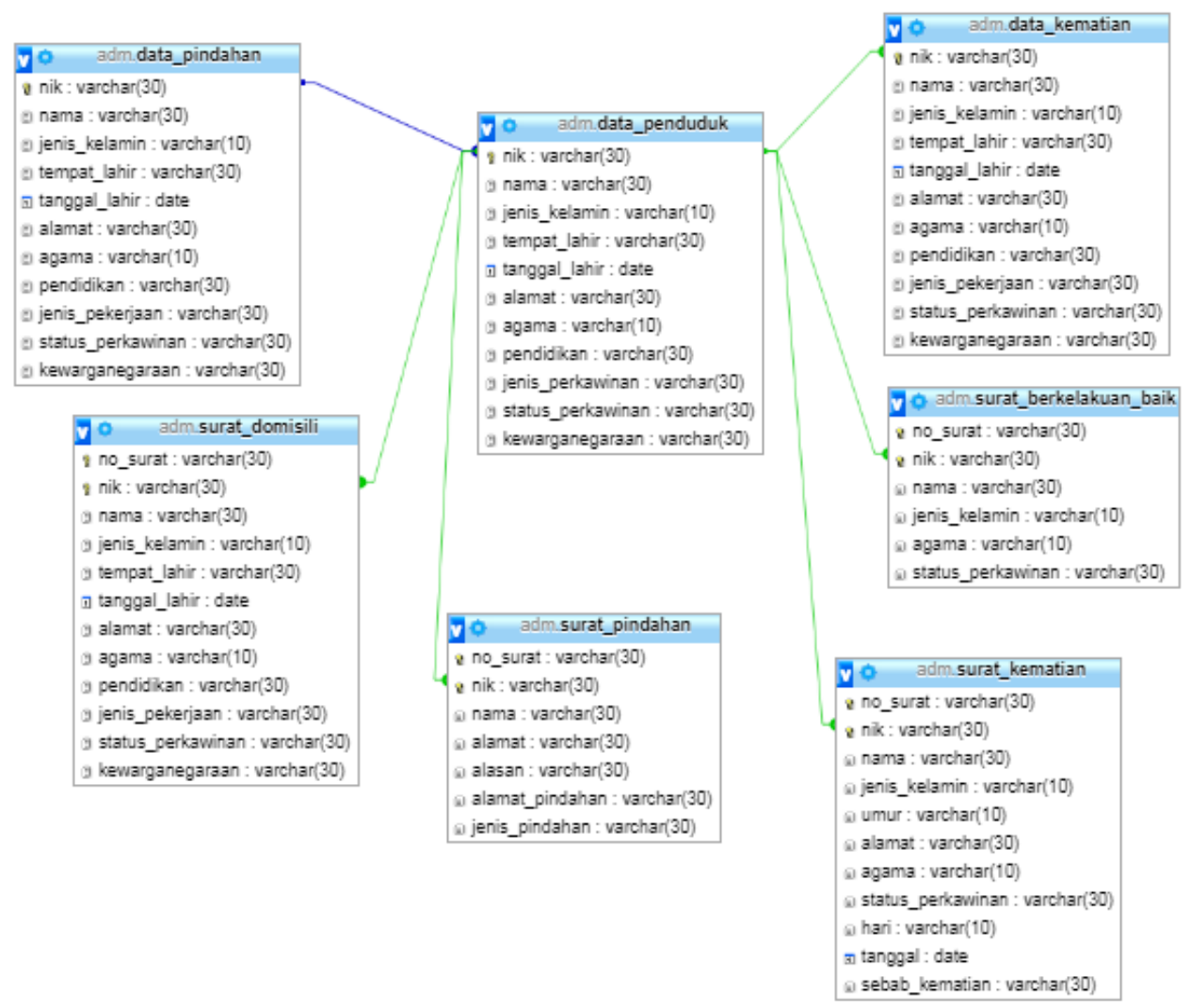

Gambar 5. Relasi database

\section{Hasil dan Pembahasan}

Pada halaman ini akan menjelaskan mengenai login pihak admin. Sebelum masuk kedalam menu hak akses admin untuk menginput surat, melihat surat dan laporan diwajibkan terlebih dahulu mengisi username dan password secara benar.

\section{SILAHKAN ISI}

\begin{tabular}{l}
\hline USERNAME \\
\hline Username \\
PASSWORD \\
\hline Password \\
\hline MASUK \\
\hline \\
RESET
\end{tabular}

Gambar 6. Menu Login

\subsection{Halaman utama}

Pada halaman ini menjelaskan mengenai hak-hak akses sebagai admin. Setelah masuk kedalam halaman utama disini terdapat beberapa menu diantaranya data penduduk, data pindahan, data kematian, surat domisili, surat pindahan, surat berkelakuan baik, surat kematian dan laporan. Halaman utama admin bisa dilihat pada Gambar 7. 


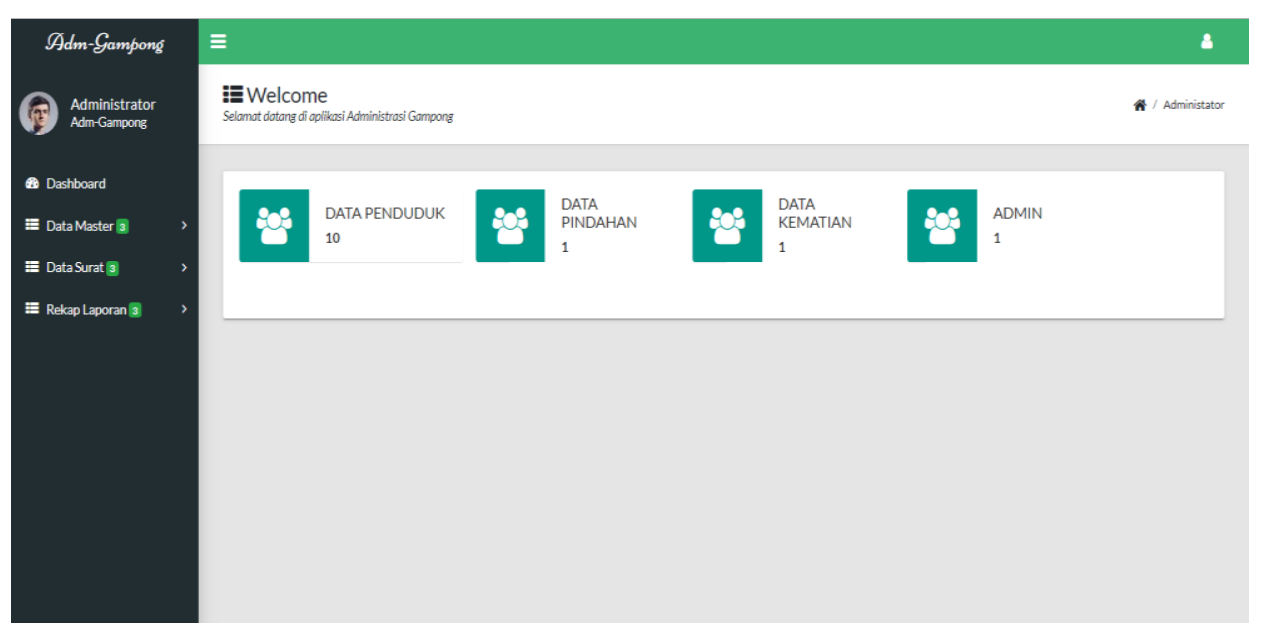

Gambar 7. Menu utama

\subsection{Input data penduduk}

Menu input data penduduk adalah menu menginput, mengedit, dan membatalkan data penduduk. Untuk lebih jelas bisa dilihat pada Gambar 8.

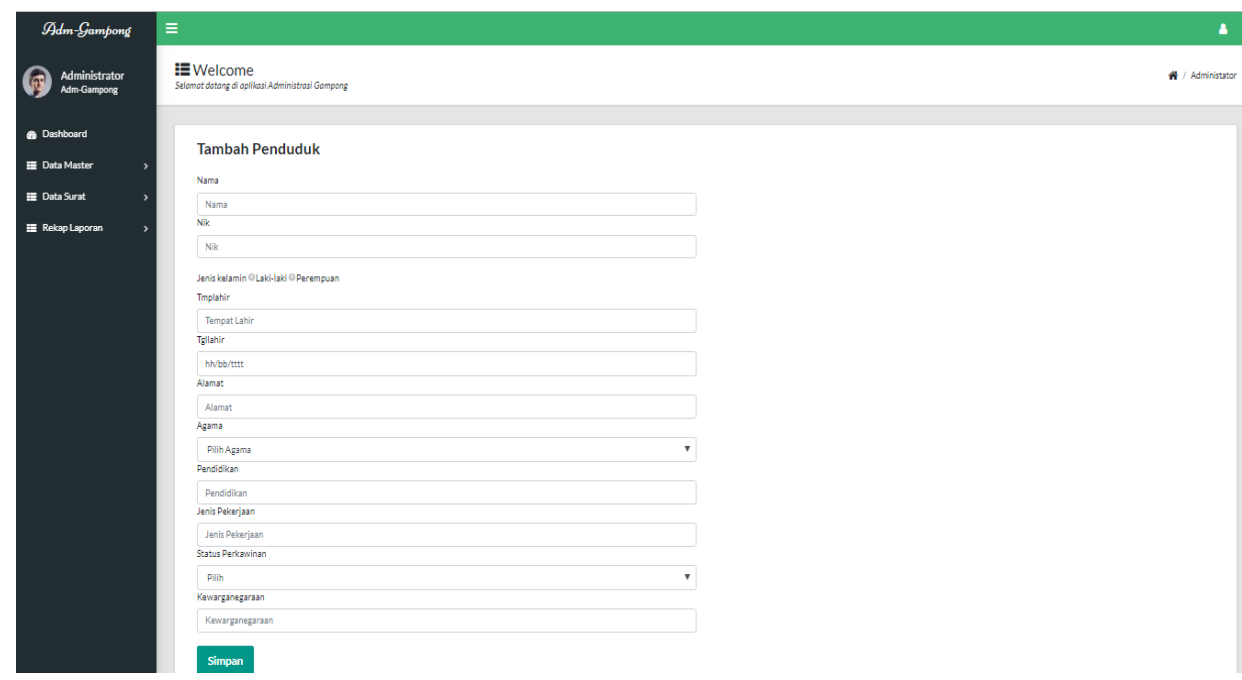

Gambar 8. Data penduduk

\subsection{Halaman data penduduk}

Menu data penduduk adalah menu mengedit, dan membatalkan data penduduk. Untuk lebih jelas bisa dilihat pada Gambar 9.

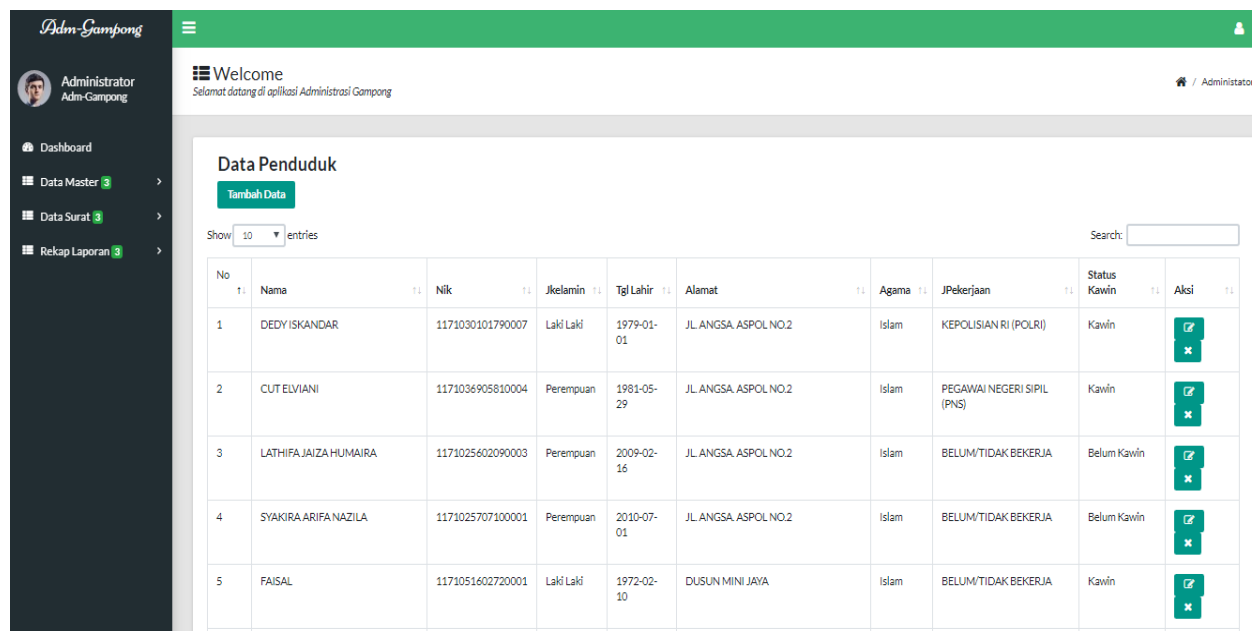

Gambar 9. Halaman data penduduk 


\subsection{Input data pindahan}

Menu input data pindahan adalah menu menginput, mengedit, dan membatalkan data pindahan penduduk. Untuk lebih jelas bisa dilihat pada Gambar 10.

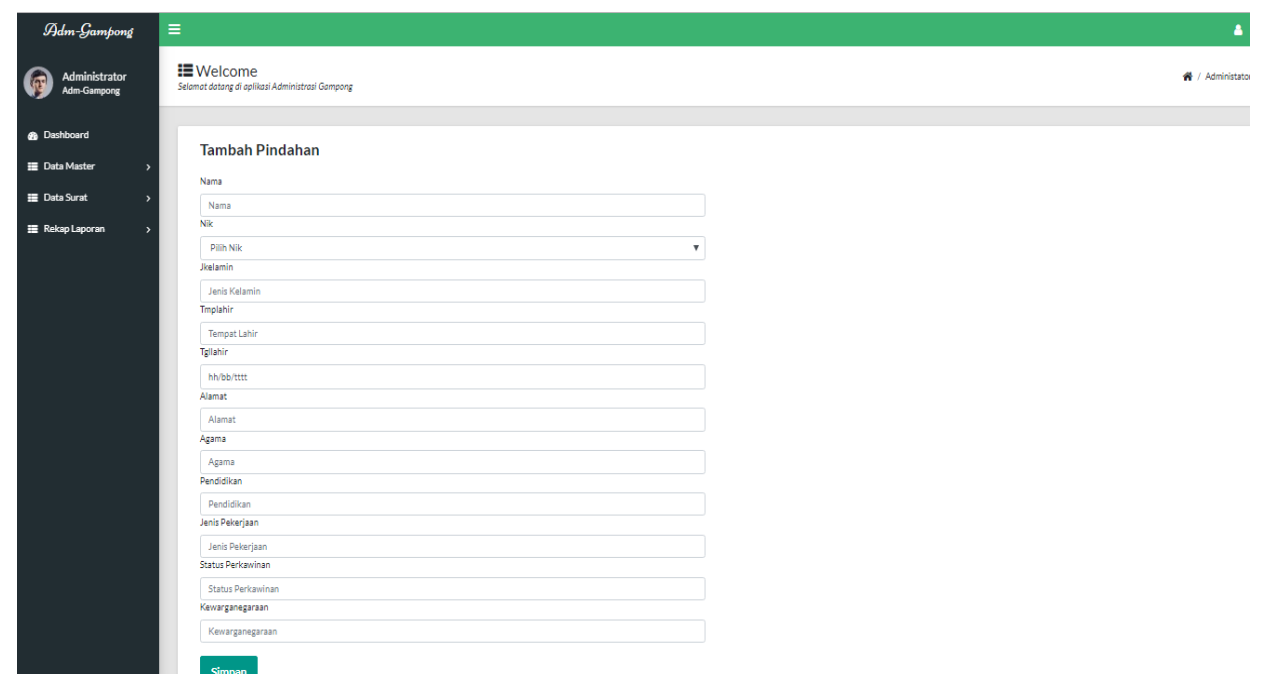

Gambar 10. Input data pindahan

\subsection{Halaman data kematian}

Menu data kematian adalah menu mengedit, dan membatalkan data kematian penduduk. Untuk lebih jelas bisa dilihat pada Gambar 11.

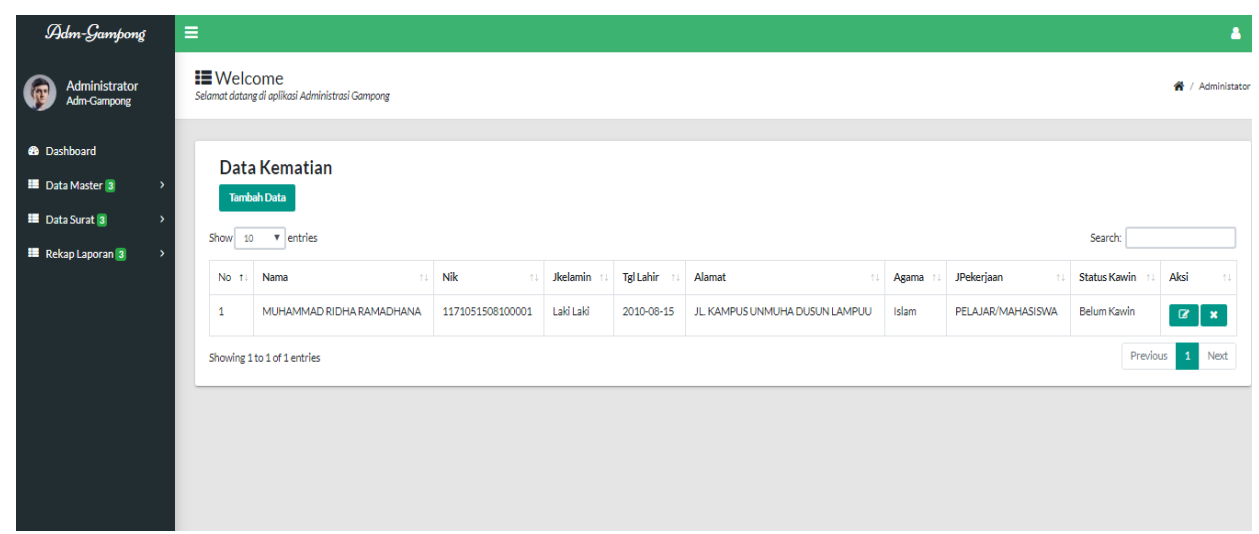

Gambar 11. Data kematian

\subsection{Data Domisili}

Menu data surat domisili adalah menu menginput, mengedit, dan membatalkan data surat Domisili Penduduk. Untuk lebih jelas bisa dilihat pada Gambar 12.

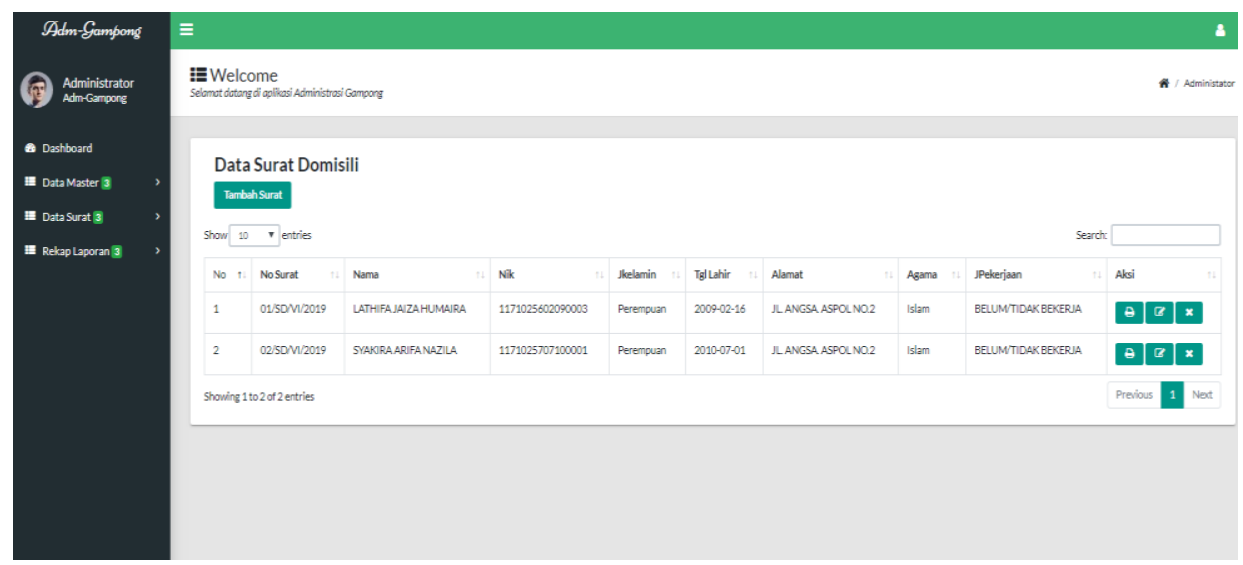

Gambar 12. Domisili 


\subsection{Laporan Surat Berkelakuan Baik}

Laporan data surat berkelakuan baik adalah form untuk mencetak laporan dari tabel surat berkelakuan baik. Untuk lebih jelas bisa dilihat pada Gambar 13.

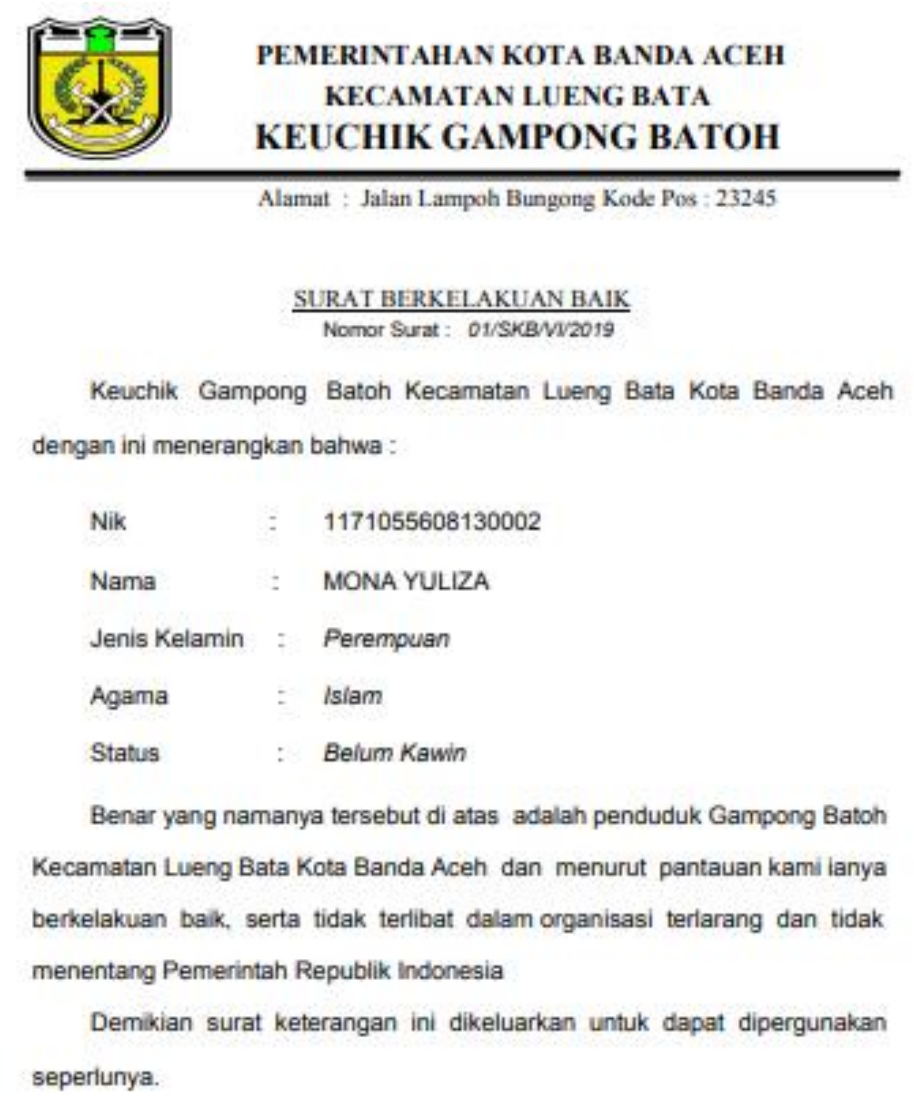

Banda Aceh : 03/09/2019

Keuchik Gampong Bathoh

AHMAD

Gambar 13. Surat berkelakuan baik

\subsection{Laporan Data Penduduk}

Laporan data penduduk adalah form untuk mencetak laporan dari tabel penduduk. Untuk lebih jelas bisa dilihat pada Gambar 14.

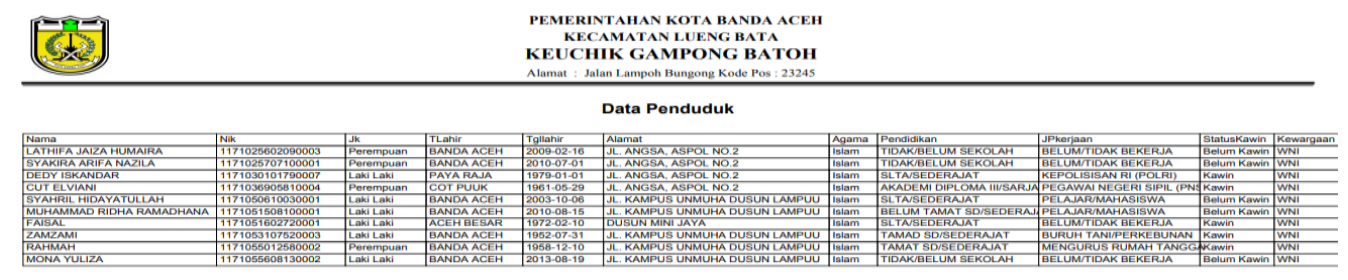

Gambar 14. Laporan data penduduk 


\section{Kesimpulan dan Saran}

Hasil dari kajian ini, sistem informasi yang dirancang dapat memberikan kemudahan serta melakukan pembaruan pengurusan administrasi Gampong. Adanya Sistem informasi ini dapat mempermudah kinerja petugas dalam pendataan, pengurusan administrasi Gampong Batoh yang sebelumnya masih menggunakan metode sistem manual.

\section{Daftar Pustaka}

[1] E. D. Saputri, S.Pd., M.H., "Analisis Pelayanan Publik Pemerintahan Desa Tlanak Kecamatan Kedungpring Kabupaten Lamongan,” JPAP J. Penelit. Adm. Publik, vol. 4, no. 1, pp. 962-968, 2018.

[2] A. Tingkat, K. Pengunjung, D. A. N. Proses, P. Keputusan, and A. B. Merapi, "Daftar Pustaka Daryanto., Ismanto Setyobudi. 2014.," pp. 73-74, 2017.

[3] E. Komara, "Kompetensi Profesional Pegawai ASN (Aparatur Sipil Negara) di Indonesia," Mimb. Pendidik., vol. 4, no. 1, pp. 73-84, 2019.

[4] M. Enita, P. Sari, P. Studi, I. Pemerintahan, and U. R. Kepulauan, “Akses Pelayanan Publik,” vol. 2, no. 1, pp. 1-12, 2018.

[5] Abdullah, "Rancang Bangun Sistem Informasi Akuntansi," Romney dan Steinbart, no. tahun 2016, pp. 7-25, 2015.

[6] F. F. D. Imaniawan and F. F. Wati, "Sistem Informasi Administrasi Kependudukan Berbasis Web Desa Sawahan," IJSE - Indones. J. Softw. Eng., vol. 3, no. 2, pp. 77-81, 2017.

[7] A. Asroni, "Penerapan Model View Controller (MVC) Dengan Framework Codeigniter Pada Sistem Informasi Booking Wisata Klangon," BERDIKARI J. Inov. dan Penerapan Ipteks, vol. 6, no. 2, pp. 119-130, 2018.

[8] P. Studi, P. Matematika, F. Matematika, D. A. N. Ilmu, P. Alam, and U. Jember, "Digital Digital Repository Repository Universitas Universitas Jember Jember Digital Digital Repository Repository Universitas Universitas Jember Jember Text Mining pada Media Sosial Twitter,” 2017.

[9] A. Andoyo and A. Sujarwadi, "Sistem Informasi Berbasis Web Pada Desa Tresnomaju Kecamatan Negerikaton Kab. Pesawaran Andreas Andoyo, M.T.I., Ahmad Sujarwadi STMIK Pringsewu Lampung Jl. Wisma Rini No.09 Pringsewu.Telp/Fax.(0729)22240. www.stmikpringsewu.ac.id,” J. TAM (Technology Accept. Model ), vol. 3, pp. 1-9, 2014.

[10] R. R. Polii., "Analisa dan Perancangan Sistem Informasi Desa Berbasis Web Model Governmentto-Citizen," J. Tek. Inform. Univ. Sam Ratulangi, vol. 12, no. 1, 2017.

[11] A. Darlianto and I. Permana, "Sistem Informasi Pencatatan Surat Masuk," J. Rekayasa dan Manaj. Sist. Inf., vol. 2, no. 1, pp. 37-43, 2016.

[12] B. Good and D. Berbasis, GovernanceYang, "3) 1,2,3,” vol. 3, no. 2, pp. 99-105, 2017.

[13] R. Firmansyah and I. Saidah, "Perancangan Web Based Learning Sebagai Media Pembelajaran Berbasis Ict," Informatika, vol. 3, no. September, pp. 176-182, 2016.

[14] Y. F. dan J. Waterkamp, "Jurnal Sistem Informasi ( Journal of Information Systems ). 2 / 13 ( 2017 ), 103-109 DOI : http://dx.doi.org/10.21609/jsi.v13i2.545,” Anal. Dan Perenc. Strateg. Sist. Dan Teknol. Inf. Menggunakan Balanc. Scorec. Pada Inst. Bisnis Dan Inform. Kwik Kian Gie, vol. 13, pp. 103-109, 2017.

[15] R. Afyenni, "Perancangan Data Flow Diagram untuk Sistem Informasi Sekolah (Studi Kasus Pada SMA Pembangunan Laboratorium UNP)," Teknoif, vol. 2, no. 1, pp. 35-39, 2014.

[16] M. Fikry, T. Informatika, and U. Malikussaleh, "Rancangan Basis Data Kependudukan Berdasarkan Aspek-Aspek Kualitas Schema Database," Techsi, vol. 8, no. 2, pp. 28-43, 2016. 